\title{
PENEGAKAN HUKUM TERHADAP PELAKU PENCEMARAN LINGKUNGAN MELALUI PEMBUANGAN AIR LIMBAH DOMESTIK DI TELUK KENDARI
}

\author{
Rima Anggriyani ${ }^{1}$; Muryanto Lanontjii ${ }^{2}$; Nofianti Rusdi ${ }^{3}$; Denty Tri Septiawani Daoed ${ }^{4}$ \\ ${ }^{123}{ }^{4}$ Program Studi Ilmu Hukum, Fakultas Hukum Universitas Muhammadiyah Kendari \\ e-mail: rimaanggriyani@umkendari.ac.id, “muryanto@umkendari.ac.id, \\ nofiantirusdi234@gmail.com, dentydaoed49@gmail.com
}

\begin{abstract}
ABSTRAK: Meskipun telah ada Perda Limbah Domestik di Kota Kendari, air limbah domestik tetap saja menjadi ancaman pencemaran terhadap teluk Kendari. Pembuangan air limbah domestik secara serampangan tanpa mengindahkan prosedur berdampak pada pencemaran teluk Kendari. Metode penelitian ini menggunakan pendekatan yuridis normatif serta yuridis empiris yaitu pendekatan yang berpedoman pada peraturan-peraturan, buku-buku atau literatur-literatur hukum serta bahan-bahan yang mempunyai hubungan permasalahan dan pembahasan dalam penulisan penelitian ini dan pengambilan data langsung pada obyek penelitian. Kesimpulan penelitian ini terdiri dari: a). Meskipun telah diatur melalui Peraturan Daerah Kota Kendari Nomor 3 Tahun 2016 tentang Pengelolaan Air Limbah Domestik, pengelolaan air limbah domestik yang dibuang ke teluk Kendari terbukti tidak optimal. Telah terjadi pada titik tertentu terbukti adanya penurunan kualitas air selain itu drainase dimana para warga menyalurkan limbah domestiknya tanpa diolah terlebih dahulu bermuara ke teluk Kendari. Hal ini tidak sejalan dengan Pasal 16 Perda Nomor 3 Tahun 2016 ayat (1) dan (2)., b) Pengawasan pengelolaan limbah domestik di teluk Kendari sangat tidak efektif. Personil yang ada pada Seksi Kebersihan Teluk dan Pesisir Dinas LH Kota Kendari jumlanya 3 (tiga) orang. Sementara aparat SatPol yang menegakkan peraturan daerah selain jumlahnya terbatas juga tidak didukung parasana kendaraan yang cukup. Terbukti ditemukan adanya kendala yang terdiri dari: 1). Minimnya jumlah personil untuk mengawasi, 2). Jumlah anggaran yang terbatas, 3).Prasarana yang sudah tidak memadai baik dari segi kondisi maupun jumlahnya.
\end{abstract}

Kata Kunci: Air Limbah; Pembuangan; Penegakan hukum; Teluk.

Abstract: Even though there is a Domestic Waste Regulation in Kendari City, domestic wastewater still poses a threat of pollution to the Kendari bay. Indiscriminate disposal of domestic wastewater without regard to procedure impacts on Kendari bay pollution. This research method uses a normative juridical approach and empirical juridical approach that is guided by regulations, books or legal literature and materials that have a relationship problem and discussion in writing this research and taking data directly on the object of research. The conclusions of this study consisted of: a). Even though it has been regulated through Kendari City Regulation Number 3 of 2016 concerning Domestic Waste Water Management, the management of domestic wastewater discharged into Kendari bay has proven to be not optimal. At a certain point, there has been evidence of a decrease in water quality, in addition to the drainage where residents channel their domestic waste without being processed first, which leads to the Kendari bay. This is not 
in line with Article 16 of Regional Regulation No. 3 of 2016 paragraph (1) and (2)., B) Supervision of management of domestic waste in Kendari bay is very ineffective. There are 3 (three) personnel in the Bay and Coastal Cleanliness Section of the Kendari City Environment Office. While the SatPol apparatus that enforces local regulations in addition to a limited number is also not supported by a sufficient vehicle. Proven found that there are obstacles that consist of: 1). The lack of personnel to oversee, 2). Limited amount of budget, 3). Inadequate infrastructure both in terms of conditions and the amount.

Keywords: Wastewater; Disposal; Law Enforcement; Gulf.

\section{PENDAHULUAN}

Kota Kendari yang berada di bibir teluk sangat tergantung dengan kelestarian teluk itu sendiri agar tetap menjadi kota teluk yang indah dan sehat. Keberadaan teluk yang berdampingan dengan Kota Kendari sangat memberi manfaat baik dari segi panorama ataupun hasil laut yang terkandung dalam lingkungan teluk. Hasil laut yang berupa biota yang ada di teluk Kendari umumnya seperti ikan serta kerang juga dikonsumsi oleh warga.

Seiring dengan perkembangan Kota Kendari yang begitu pesat maka berdampak juga terhadap teluk Kendari. Dampak negatif yang timbul adalah pencemaran lingkungan terhadap teluk tersebut. Ancaman yang nyata terlihat adalah air limbah domestik baik oleh rumah tangga ataupun badan usaha yang berupa hotel atau ruko, atau sarana umum lainnya (tempat hiburan atau tempat wisata teluk). Air limbah jenis ini umumnya dibuang ke teluk Kendari oleh mereka yang bermukim di sekitar teluk. Pencemaran itu dipastikan terjadi ketika pengelolaan air limbah domestik itu tidak sesuai standar baku mutu air limbah yang ditetapkan.

Adapun yang dimaksud dengan air limbah dalam lingkup daerah diatur dalam Peraturan Daerah Kota Kendari Nomor 3 Tahun 2016 tentang Pengelolaan Air Limbah Domestik (selanjutnya disebut Perda Limbah Domestik). Dengan aturan yang bersifat lokal ini diharapkan produk limbah yang ada di masyarakat dapat diatur secara baik.

Akan tetapi, meskipun telah ada Perda Limbah Domestik di Kota Kendari, air limbah domestik tetap saja menjadi ancaman pencemaran terhadap teluk Kendari. Pembuangan air limbah domestik secara serampangan tanpa mengindahkan prosedur berdampak pada pencemaran teluk Kendari. Mongabay, sebuah situs berita lingkungan pada 12 Desember 2017 silam memberitakan bahwa Data Dinas Kelautan dan Perikanan (DKP) Kota Kendari, menyebutkan, hutan Mengrove Kendari menyusut dari 525 hektar menjadi 367,5 hektar. Penyebabnya selain proses pembangunan, juga pengaruh bahan kimia berbahaya diakar Mangrove (http://www.mongabay.co.id/2017/12/12/kalateluk-kendari-tercemar-merkuri-dan-limbah-b3/. diakses Minggu, 30 Desember 2018). Air yang telah tercemar itu nantinya cepat atau lambat akan menimbulkan dampak sosial karena air merupakan penunjang kehidupan manusia atau mahluk hidup secara luas. Untuk itu memulihkan air yang tercemar kembali seperti sediakala perlu waktu yang banyak.

Atas fakta yang terjadi di teluk Kendari tersebut selain mengancam ekosisten yang ada juga terhadap masyarakat yang mengambil manfaat dari hasil laut di teluk Kendari. Dengan mengkonsumsi hasil laut yang tercemar jelas akan berbahaya bagi 
kesehatan masyarakat. Menyadari potensi bahaya tersebut maka menarik untuk melakukan penelitian berupa analisis hukum atas pembuangan air limbah domestik terkait pencemaran di teluk Kendari.

Tujuan penelitian hukum ini yaitu : 1). Untuk mengetahui pengelolaan air limbah domestik yang dibuang ke teluk Kendari sesuai Peraturan Daerah Kota Kendari Nomor 3 Tahun 2016 tentang Pengelolaan Air Limbah Domestik. 2).Untuk mengetahui pengawasan pengelolaan air limbah domestik yang dibuang ke teluk Kendari sesuai Peraturan Daerah Kota Kendari Nomor 3 Tahun 2016 tentang Pengelolaan Air Limbah Domestik.

\section{METODE PENELITIAN}

Pendekatan yang digunakan terhadap penelitian ini adalah pendekatan yuridis normatif serta yuridis empiris. Dengan pendekatan yuridis normatif yaitu mengambil isu dari hukum sebagai sistem norma yang digunakan untuk memberikan "justifikasi" preskriptif tentang suatu peristiwa hukum (Mukti Fajar dan Yulianto Achmad, 2010:36). Dengan pendekatan yuridis empiris yaitu pendekatan yang berpedoman pada peraturan-peraturan, buku-buku atau literatur-literatur hukum serta bahan-bahan yang mempunyai hubungan permasalahan dan pembahasan dalam penulisan penelitian ini dan pengambilan data langsung pada obyek penelitian (Ronny Hanitijo Soemitro, 2001:10).

Sumber dan jenis data dalam penelitian ini yaitu Data Primer yakni data yang diperoleh langsung dari sumber pertama (Amirudin\& Zainal Asikin, 2014:30). Data yang demikian umumnya dilakukan dengan cara wawancara secara langsung ke sumber informasi (narasumber). Data ini sangat terkait erat dengan informan yang akan diwawancarai dalam penelitian ini. Data Sekunder antara lain mencakup dokumendokumen resmi, buku-buku, hasil-hasil penelitian yang berwujud laporan, dan sebagainya (Amirudin\& Zainal Asikin, 2014:30). Bahan Hukum Primer merupakan bahan hukum yang sifatnya mengikat berupa perundang-undangan yang berlaku. Bahan hukum yang memberikan penjelasan mengenai bahan hukum primer yang meliputi buku-buku atau literatur-literatur yang berhubungan dengan pembuangan air limbah terkait pencemaran di teluk Kendari. Bahan hukum tersier yang memberi penjelasan tentang bahan hukum primer maupun sekunder. Bahan ini umumnya diperoleh memalui kamus hukum, kamus bahasa Indonesia serta kamus bahasa Inggris.

Informan adalah orang atau individu yang memberikan informasi data yang dibutuhkan oleh peneliti sebatas yang diketahuinya dan peneliti tidak dapat mengarahkan jawaban sesuai dengan yang diinginkannya. (Mukti Fajar dan Yulianto Achmad:175) Adapun informan penelitian ini meliputi: 1 (satu) orang pegawai Dinas Lingkungan Hidup Kota Kendari; 1 (satu) anggota DPRD yang membidangi Lingkungan Hidup; dan 1 (satu) orang Akademisi. Metode Pengumpulan: 1)Studi Kepustakaan merupakan cara pengumpulan data dengan membaca, memahami, mengutip, merangkum, dan membuat catatan-catatan serta menganalisis peraturan perundangundangan. 2) Studi Lapangan dilaksanakan dalam rangka mendapat data primer melalui metode wawancara langsung ke informan sebagai narasumber yang kompeten sehubungan pengumpulan data dalam penelitian ini. Dalam mengolah data, peneliti 
dalam kegiatannya menempuh prosedur-prosedur sebagai berikut : Seleksi data, Klasifikasi data dan Sistimatisasi data.

Data yang telah ditetapkan kemudian dianalisis secara kualitatif yakni dengan cara menguraikan segala fakta empiris yang berlandaskan hasil penelitian. Bertolak dari analisis yang telah dilakukan maka dihasilkan kesimpulan melalui metode induktif yakni melalui pemikiran yang khusus untuk suatu kesimpulan yang umum untuk menjawab masalah yang telah diajukan.

\section{HASIL PENELITIAN DAN PEMBAHASAN}

Pengelolaan Air Limbah Domestik yang Dibuang ke Teluk Kendari Sesuai Peraturan Daerah Kota Kendari Nomor 3 Tahun 2016 tentang Pengelolaan Air Limbah Domestik

Pengelolaan air limbah domestik yang dibuang ke teluk Kendari membutuhkan kajian ilmiah karena wilayah Kota Kendari secara geografis berada di sekeliling teluk tersebut. Dari 11 (sebelas) kecamatan di Kota Kendari 7 diantara memiliki kelurahan yang berlokasi di tepi laut yang artinya sebagian besar berada di tepi teluk Kendari. Badan Pusat Statistik (BPS) Kota Kendari dalam buku Katalog yang berjudul "Kota Kendari Dalam Angka Kendari Municipality in Figures 2018" di halaman 37 menyajikan secara detail berikut ini :

Tabel 1. Jumlah Kelurahan menurut Kecamatan dan Letak Geografi di Kota Kendari, 2017

\begin{tabular}{clcc}
\hline No. & \multicolumn{1}{c}{ Kecamatan } & $\begin{array}{c}\text { Kelurahan } \\
\text { Tepi Laut }\end{array}$ & $\begin{array}{c}\text { Kelurahan } \\
\text { Bukan Tepi Laut }\end{array}$ \\
\hline 1 & Mandonga & 1 & 5 \\
\hline 2 & Baruga & - & 4 \\
\hline 3 & Puuwatu & - & 6 \\
\hline 4 & Kadia & - & 5 \\
\hline 5 & Wua-Wua & - & 4 \\
\hline 6 & Poasia & 4 & 1 \\
\hline 7 & Abeli & 4 & 3 \\
\hline 8 & Kambu & 2 & 2 \\
\hline 9 & Nambo & 5 & 1 \\
\hline 10 & Kendari & 6 & 3 \\
\hline 11 & Kendari Barat & 8 & 1 \\
\hline
\end{tabular}

Data: BPS Kota Kendari 2018

Dari gambaran data yang disajikan BPS tersebut menggambarkan betapa pentingnya menjaga kelestarian teluk Kendari. Diketahui, dari 7 kecamatan di tepi laut secara keseluruhan ada 30 kelurahan di tepi laut. Data tersebut sama artinya bahwa sebagian besar jumlah wilayah kecamatan di Kota Kendari memiliki akses ke teluk Kendari. Patut dipahami bahwa wilayah kecamatan di tepi laut itu merupakan wilayah yang diami penduduk yang potensial menghasilkan limbah domestik. Pada akhirnya ancaman polusi yang berasal dari limbah domestik yang dihasilkan badan usaha atau rumah tangga merupakan ancaman terbesar jika semua dibuang ke teluk tanpa diolah terlebih dahulu agar ramah lingkungan. 
Dengan kondisi geografi serta kondisi kota yang terus berkembang maka dibutuhkan sebuah pengelolaan yang bijaksana sehubungan limbah domestik di Kota Kendari. Sebagai kota yang mengitari teluk Kendari adalah wajar untuk menjaga kelestarian teluk dimana secara sosial dan ekonomi dibutuhkan warganya. Pengelolaan air limbah domestik yang dibuang ke teluk Kendari sesuai Peraturan Daerah Kota Kendari Nomor 3 Tahun 2016 tentang Pengelolaan Air Limbah Domestik, untukl selanjutnya disebut Perda Air Limbah Domestik, dalam penelitian ini disesuaikan dengan kondisi empirik. Hal ini penting untuk melihat persesuaian antara pengelolaan air limbah domestik di Teluk Kendari dengan norma hukum yang berlaku.

Pengelolan air limbah domestik dikatakan telah optimal ketika pengelolaannya telah sesuai dengan tujuan yang diharapkan. Tujuan dari pengelolaan air limbah domestik di Kota Kendari mengacu pada Pasal 4 Perda Air Limbah Domestik:

"Tujuan pengelolaan air limbah domestik adalah:

a. terkendalinya pembuangan air limbah domestik;

b. terlindunginya kualitas air tanah dan air permukaan; dan

c. meningkatkan upaya pelestarian fungsi lingkungan hidup khususnya sumber daya air."

Untuk melihat sejauh mana pengelolaan air limbah domestik di Kota Kendari, maka perlu untuk mendapatkan informasi dari instansi yang berkompeten. Terkait limbah, merupakan tugas pokok dan fungsi (Tupoksi) Dinas Lingkungan Hidup dan Kehutanan Kota Kendari.

Dari informasi yang disampaikan, Tajwid, Kepala Bidang (Kabid) Persampahan Dinas Lingkungan Hidup dan Kehutanan Kota Kendari (Dinas LH Kota Kendari), penanganan limbah cair masih minim sekali, hal ini dibuktikan adanya 700 unit rumah tangga yang tidak memiliki septic tank di Kota Kendari termasuk yang bermukim di sekitar teluk Kendari.

"Yang sekarang dimasifkan adalah soal penanganan black water (tinja). Dalam pembuatan dokumen lingkungan dipersyaratkan bahwa black water (tinja) harus ditreatment pada septic tank yang sesuai standar SNI." (Wawancara, Tajwid, Kabid Persampahan Dinas LH Kota Kendari Dinas Lingkungan Hidup dan Kehutanan Kota Kendari, Rabu 28 Agustus 2019)

Upaya penanganan limbah domestik secara masif tersebut akan menemui kendala dari aspek pengawasan karena laboratorium dari Dinas Lingkungan Hidup belum berfungsi maksimal akibat permasalahan anggaran. Kondisi ini kurang menguntungkan untuk jangka panjang karena pengelolaan black water milik masyarakat hanya $20 \%$ memenuhi syarat belum lagi limbah mandi-cuci masyarakat.

Fakta yang dikemukakan Kabid Persampahan Dinas LH Kota Kendari tersebut belum menunjukkan ancaman limbah domestik secara langsung ke Teluk Kendari. Akan tetapi fenomena tersebut merupakan indikasi bahwa pengelolaan limbah domestik yang belum optimal. Menjadi ancaman bagi teluk Kendari ketika terbukti bahwa air limbah domestik produk warga tanpa septic tank itu memang di buang ke pesisir teluk Kendari. 


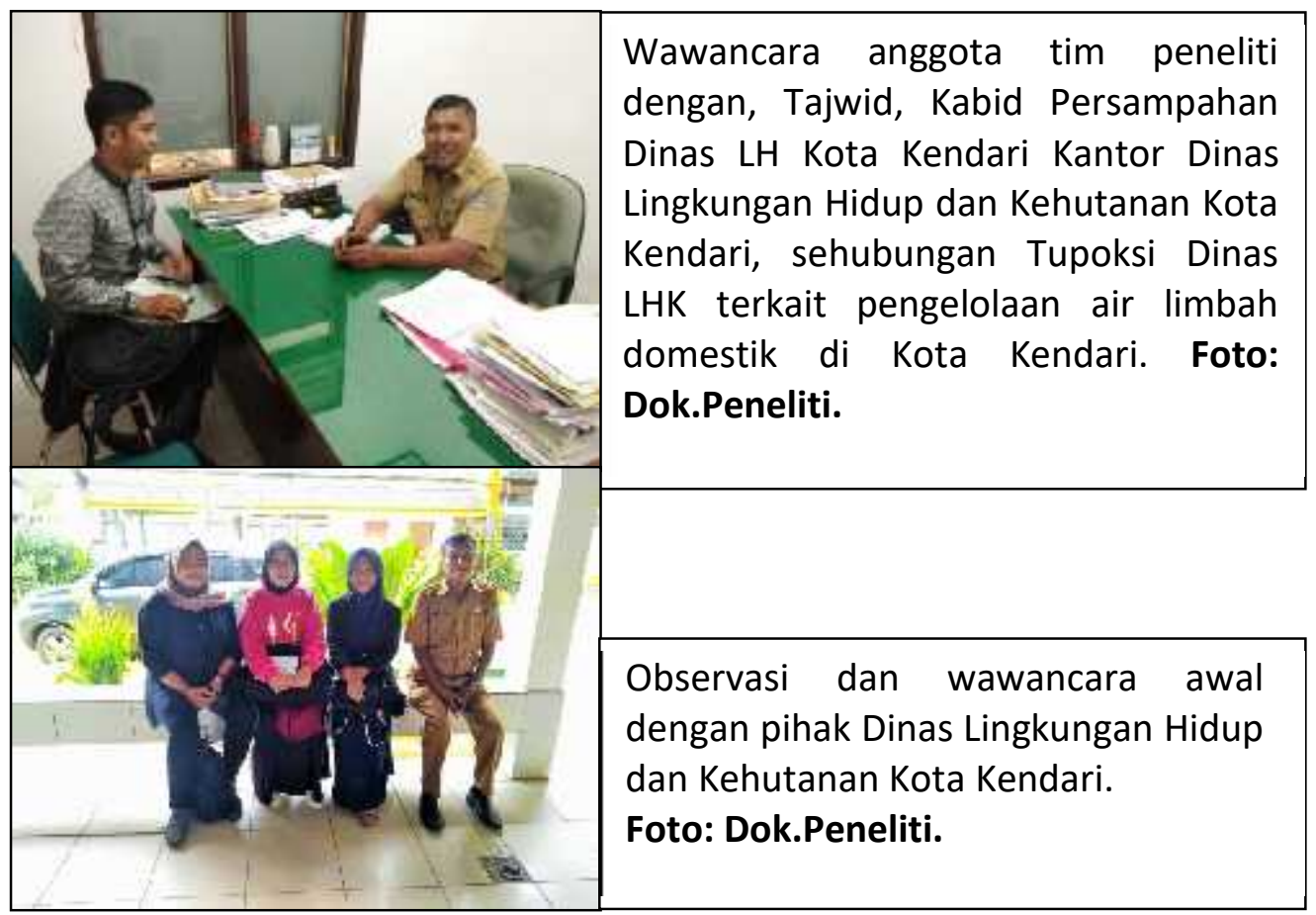

Gambar 1. Wawancara dengan narasumber

Fakta lain secara kasat mata yang tampak adalah sungai-sungai kecil dari arah pemukiman penduduk di Kota Kendari umumnya bermuara di teluk kota tersebut. Umumnya, dari drainase yang ada di Kota Kendari dimana warga mengalirkan limbah domestiknya mengarah ke teluk Kendari. Hasil observasi di Kelurahan Tipulu dan Kemaraya di Kecamatan Kendari menjukkan adanya sungai kecil dari arah perbukitan melintasi pemukiman warga kemudioan bermuara ke teluk. Hampir keseluruhan warga yang dilintasi sungai kecil itu terlihat pembuangan air mandi dan cuci (limbah domestik) dialirkan ke sungai kecil dimaksud. Harusnya limbah itu diolah terlebih dahulu agar sesuai baku mutu air limbah. Dengan pengolahan dimaksud air pembuangan warga memenuhi standar yang ditentukan pemerintah.

Ditambahkan oleh Kabid Persampahan Dinas LH Kota Kendari, ancaman pencemaran di teluk Kendari tidak saja dari limbah domestik. Limbah kimia juga dalam pantauaan pihak. Di daerah Kelurahan Kandai atau istilah dimasyarakat disebut "Kota Lama" berjajar rumah-rumah para perajin emas tetapi tidak diketahui limbah mereka dibuang kemana. Bahkan fakta yang nyata atas penecemaran kimiawi itu telah ditemukan pihaknya bahwa adanya limbah berupa tumpahan oli dari bengkel dibuang ke anak sungai yang mengarah ke teluk di Kelurahan Kemaraya, Kecamatan Kendari Barat. "Ada bengkel di daerah itu membuang tumpahan oli bekasnya di anak sungai yang menuju ke teluk." (Wawancara, Tajwid, Kabid Persampahan Dinas LH Kota Kendari Dinas Lingkungan Hidup dan Kehutanan Kota Kendari, Rabu 28 Agustus 2019).

Fakta lainnya adalah temuan dari pihak Fakultas Perikanan dan Kelautan (FPIK) Universitas Muhammadiyah Kendari (Unismuh Kendari), bahwa kualitas air laut di kawasan teluk Kendari yang berada tidak jauh depan Swiss Bel Hotel Kendari (Kecamatan Kendari Barat) mengalami penurunan. Anwar Said, S.Si.,M.Si., akademisi FPIK Universitas Muhammadiyah Kendari, dengan mekanisme In Situ dilakukan sampling 
secara acak di 3 (tiga) titik di Teluk Kendari masing-masing di sekitar Masjid Al Alam, Jembatan Tripping dan depan Swiss Bell hotel. Di dua titik lainya kondisi air laut normal. Namun di lokasi depan Swiss Bel hotel air lautnya mengalami perubahan bau, biota lautnya juga tidak ditemukan. "Di lokasi depan Swiss Bell ini jelas kualitas airnya mengalami penurunan." (Wawancara, Anwar Said, S.Si., M.Si., di Universitas Muhammadiyah Kendari, Kamis, 12 September 2019)

Berdasarkan observasi dan keterangan 2 (dua) informan di atas membuktikan bahwa kawasan Kemaraya dan laut di depan Swiss Bel hotel merupakan wilayah yang saling berdampingan di Kecamatan Kendari Barat. Secara faktual juga di kelurahan Kemaraya ditemukan warga yang membuang limbah domestik ke sungai kecil ke arah laut teluk Kendari. Fakta lainnya, air laut di depan Swiss Bel hotel mengalami perubahan bau.

Berdasarkan fakta-fakta yang telah diuraikan bahwa pengelolaan air limbah domestik belum optimal. Air limbah domestik yang tidak diolah sebagaimana Pasal 16 Perda Nomor 3 Tahun 2016 ayat (1) dan (2), menyatakan :

“(1). Setiap orang yang melakukan pembuangan air limbah domestik melalui media lingkungan dan/atau jaringan perpipaan air limbah sistem terpusat wajib melakukan pengolahan awal terlebih dahulu sesuai dengan jenis kegiatannya.

(2). Air limbah yang telah diolah sebagaimana diamksud ayat (1) harus memenuhi baku mutu air limbah."

Dari ketentuan tersebut bahwa kewajiban untuk melakukan pengolahan tidak ditentukan secara khusus. Hal ini harus dimaknai bahwa siapa saja yang membuang limbah domestik dikenai keharusan untuk mengolah limbah domestiknya itu.

Pihak Dewan Perwakilan Rakyat Daerah Kota Kendari (DPRD Kota Kendari) juga menjadi obyek perhatian terkait masalah sampah di teluk Kendari. Sukarni Ali Madia, Ketua Komisi III DPRD Kota Kendari yang membidangi lingkungan hidup, mengatakan, warga yang membuang limbah domestik ke teluk Kendari masih banyak. Para pelakunya tidak sebatas rumah tangga semata tetapi juga pelaku usaha.

“Mereka yang membuang sampah atau limbah ke saluran yang diarahkan ke sungai yang menuju teluk jumlahnya masih banyak. Air limbah selain dari pemukiman juga dari rumah makan, usaha laundry." (Wawancara Sukarni Ali Madia, di ruang Komisi III DPRD Kota Kendari, Rabu 28 Agustus 2019)

Dikatakan juga oleh Ketua Komisi III DPRD Kota Kendari tersebut bahwa di masa mendatang permasalahan limbah domestik akan menjadi masalah serius di teluk Kendari jika pelaku usaha terus membuang limbah domestiknya. Menurut catatannya hingga akhir tahun 2018 ada 1.416 jenis usaha yang ada di Kota. Pesatnya populasi di sektor usaha harus disertai dengan pengawasan agar tidak meresahkan masyarakat

\section{Pengawasan Pengelolaan Air Limbah Domestik yang Dibuang ke Teluk Kendari Sesuai Peraturan Daerah Kota Kendari Nomor 3 Tahun 2016 tentang Pengelolaan Air Limbah Domestik}

Sesuai ketentuan Pasal 43 Peraturan Daerah Kota Kendari Nomor 3 Tahun 2016 tentang Pengelolaan Air Limbah Domestik, pengawasan dilakukan oleh dinas atau badan yang menangani lingkungan hidup bekerjasama dengan instansi terkait. Berdasarkan 
ketentuanya tersebut maka Dinas Lingkungan Hidup dan Kehutanan Kota Kendari (Dinas LH Kota Kendari) yang memiliki kewenangan pengawasan bekerjasama dengan instansi terkait.

Pengelolaan air limbah domestik di Kota Kendari telah ditentukan dalam Peraturan Walikota Kendari Nomor 18 Tahun 2018 tentang Penyelenggaraan Sistem Pengelolaan Air Limbah Domestik Setempat, selanjutnya disebut Perwali No.18 tahun 2018. Pasal 1 angka 12 Perwali No.18 tahun 2018 tersebut menyatakan :

"Sistem Pengelolaan air limbah domestik setempat yang selanjutnya disingkat SPALD-S adalah sistem pengelolaan yang dilakukan dengan mengolah air limbah domestik di lokasi sumber, yang selanjutnya lumpur hasil olahan diangkut dengan sarana pengangkut ke Sub-sistem Pengolahan Lumpur Tinja."

Kemudian untuk selanjutnya, pengawasan pengelolaan air limbah domestik mengacu pada petunjuk teknis yang telah diatur dalam Pasal 18 Perwali No.18 tahun 2018 :

“(1).Pengawasan pengelolaan SPALD-S dilakukan oleh Pemerintah Daerah yang dipimpin langsung Walikota;

(2). Perangkat daerah yang menangani urusan pengelolaan air limbah domestik melaporkan setiap 6 bulan sekali kepada Walikota;

(3) Walikota memimpin rapat koordionasi untuk pengawasan pelaksanaan peningkatan layanan SPALD-S setiap 6 bulan sekali.

(4). Dalam pelaksanaan pengawasan sebagaimana dimaksud pada ayat(1) perangkat daerah menetapkan indikator pengawasan yang obyektif."

Tajwid, Kabid Persampahan Dinas LH Kota Kendari, mengatakan pengawasan pengelolaan air limbah domestik yang dibuang ke teluk Kendari secara teknis dijalankan oleh Bidang Persampahan melalui Seksi Kebersihan Teluk dan Pesisir. Pada sisi lain pengawasan yang dijalankan belum efektif akibat keterbatasan sarana dan personil. Pada Seksi Kebersihan Teluk dan Pesisir di Dinas LH Kota Kendari hanya dikelola oleh 3 personil yang sangat tidak proporsional dibandingkan luas teluk Kendari $+11,36 \mathrm{~km}^{2}$ yang harus diawasi.(https://revitalisasikawasan-upn.blogspot.com/2016/06/revitalisasi -kawasan-teluk-kendari.html, diakses Sabtu 21 September 2019). Akibat personil yang tidak memadai tersebut berdasarkan rapat yang dilakukan pada tahun anggaran 2020 dilakukan penambahan personil : "Jumlah personil hanya 3 orang dan ditahun anggara 2020 dianggarkan bagi 15 orang." ((Wawancara, Tajwid, Kabid Persampahan Dinas LH Kota Kendari Dinas Lingkungan Hidup dan Kehutanan Kota Kendari, Rabu 28 Agustus 2019)) 


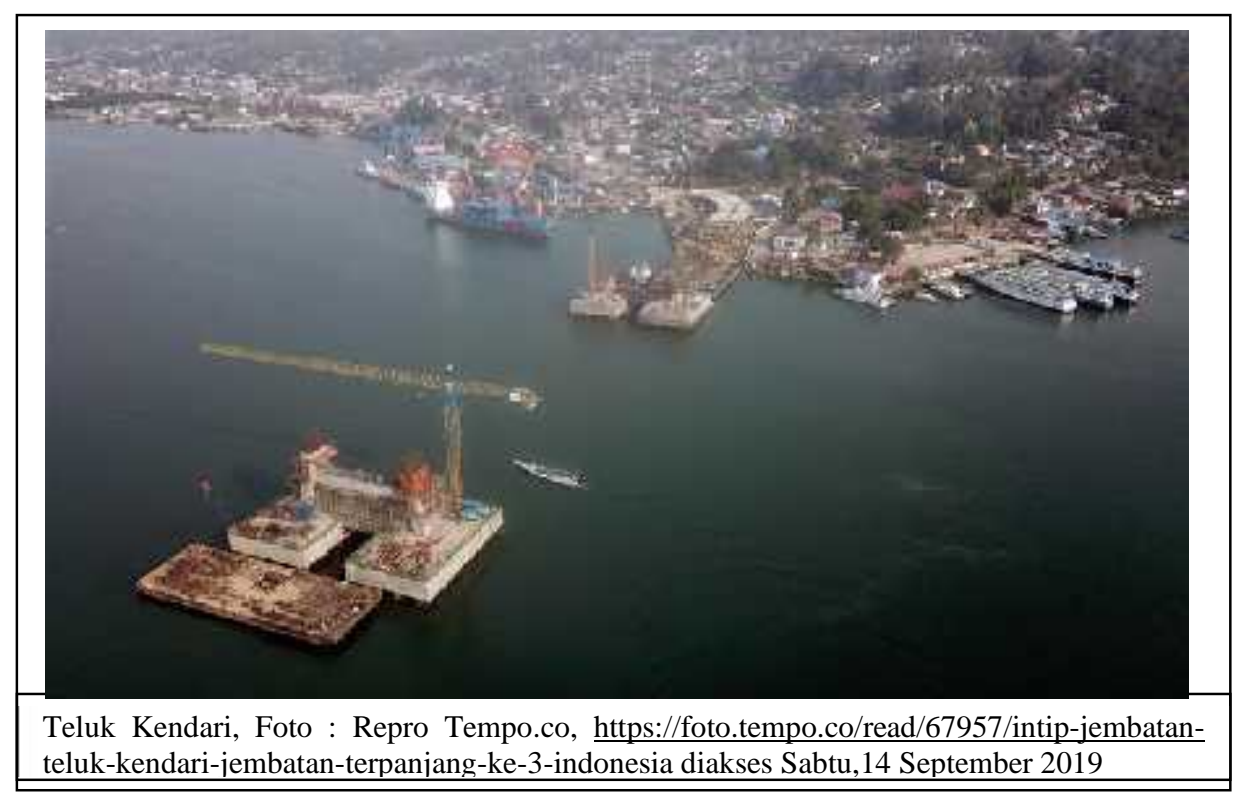

Gambar 2. Foto Teluk Kota Kendari

Akan tetapi kendala pengawasaan yang terjadi bukan hanya masalah personil, melainkan masalah dana. Luasan teluk sebagaimana disebutkan diatas ternyata hanya dibiayai dengan anggaran Rp.13 milyar yang diperuntukkan bagi pembiayaan pengelolaan sampah di Kota Kendari yang terdiri gaji personil, operasional armada sampah serta suku cadang. Prasarana kendaraan operasional yang hanya satu unit serta kondisinya kurang menunjang karena obyek pengawasannya terletak di perairan. Sebagai akibatnya dibutuhkan kendaraan yang mampu menjangkau permasalahan di teluk Kendari.

Seksi Kebersihan Teluk dan Pesisir Dinas LH Kota Kendari sangat membutuhkan kendaraan di atas air. Pengangkutan sampah dari perairan sangat membatasi ruang gerak dalam mengatasi persampahan di teluk Kendari, termasuk masalah limbah domestik di dalamnya. Mengatasi keterbatasan menghadapi pencemaran teluk pihak Dinas LH Kota Kendari berkoordinasi dengan instansi terkait seperti Syahbandar, Bea dan Cukai, SAR, TNI AL, Pol Airud dan lain sebagainya.

Kendala pengawasan pengelolaan air limbah domestik yang dibuang ke teluk Kendari itu juga diakui oleh Sukarni Alimadia, Ketua Komisi III DPRD Kota Kendari. Menurutnya, penegakan peraturan daerah dilaksanakan oleh Satuan Polisi Pamong Praja (Sat Pol PP) yang jumlahnya juga sangat terbatas selain jumlah yang terbatas kendaraan operasional juga hanya 2 (dua) unit. Di sisi lain sat Pol PP dituntut untuk Kota Kendari yang 296/ $\mathrm{km}^{2}$ persegi dengan penduduk berjumlah 370 ribu jiwa. " Idealnya anggaran yang dibutuhkan Sat Pol Rp 1,5 milyar" (Wawancara Sukarni Ali Madia, di ruang Komisi III DPRD Kota Kendari, Rabu 28 Agustus 2019) 


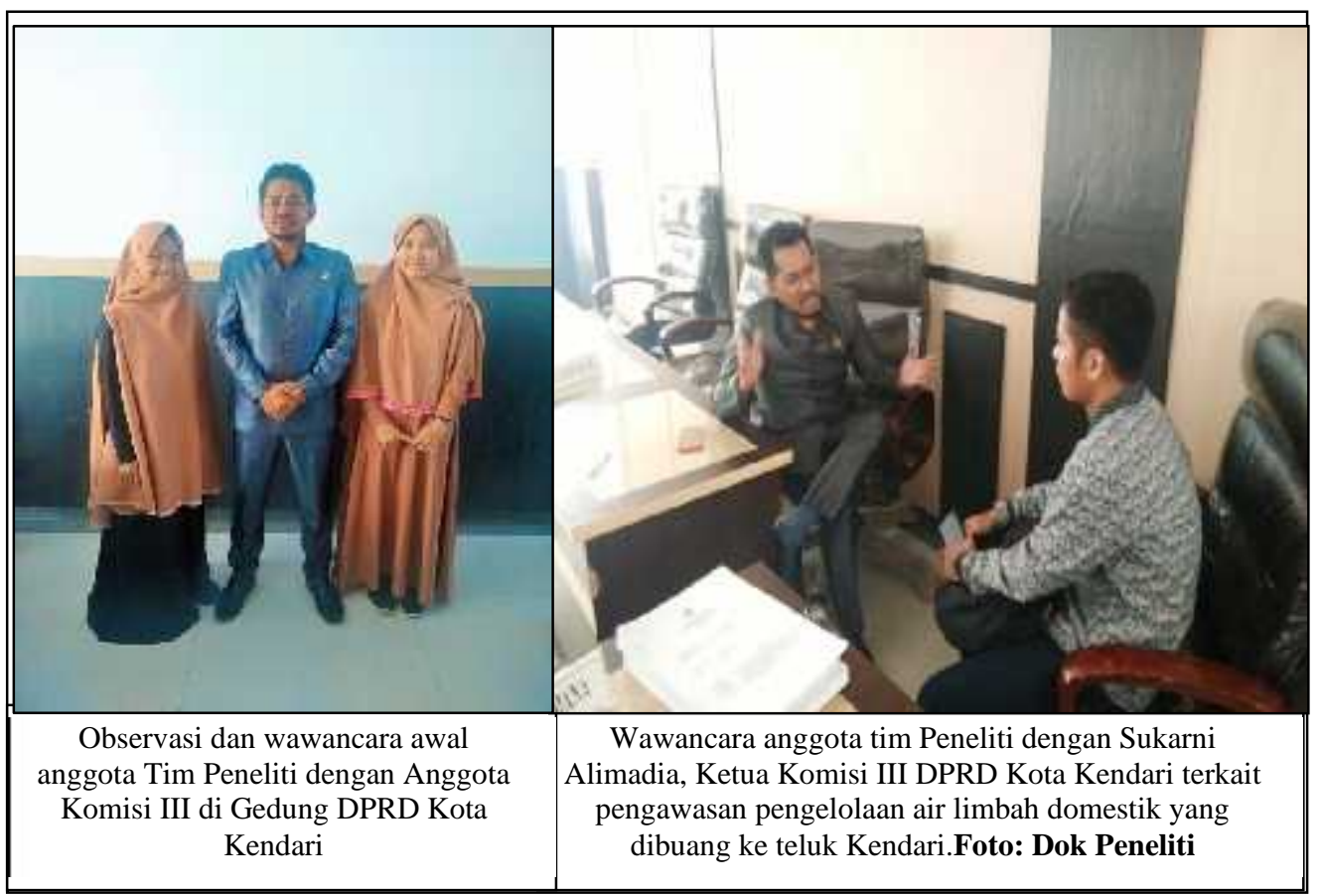

Gambar 3. Foto Wawancara Dengan Anggota DPRD Kota Kendari

Berdasarkan hal yang disampaikan oleh Tjwid dan Sukarni Alimadia tersebut diatas ditemukan fakta bahwa pengawasan pengelolaan limbah domestik di teluk Kendari sangat tidak efektif. Terbukti ditemukan adanya kendala yang terdiri dari :

1. Minimnya jumlah personil untuk mengawasi;

2. Jumlah anggaran yang terbatas;

3. Prasarana yang sudah tidak memadai baik dari segi kondisi maupuin jumlahnya.

\section{KESIMPULAN}

Berdasarkan hasil penelitian yang dilakukan maka kesimpulan yang didapat meliputi hal-hal sebagai berikut: a).Meskipun telah diatur melalui Peraturan Daerah Kota Kendari Nomor 3 Tahun 2016 tentang Pengelolaan Air Limbah Domestik, pengelolaan air limbah domestik yang dibuang ke teluk Kendari terbukti tidak optimal. Telah terjadi pada titik tertentu terbukti adanya penurunan kualitas air selain itu drainase dimana para warga menyalurkan limbah domestiknya tanpa diolah terlebih dahulu bermuara ke teluk Kendari. Hal ini tidak sejalan dengan Pasal 16 Perda Nomor 3 Tahun 2016 ayat (1) dan (2). b).Pengawasan pengelolaan limbah domestik di teluk Kendari sangat tidak efektif. Personil yang ada pada Seksi Kebersihan Teluk dan Pesisir Dinas LH Kota Kendari jumlanya 3 orang. Sementara aparat Sat Pol yang menegkkan peraturan daerah selain jumhnya terbatas juga tidak didukun parasana kendaraan yang cukup. Terbukti ditemukan adanya kendala yang terdiri dari : 1).Minimnya jumlah personil untuk mengawasi; 2).Jumlah anggaran yang terbatas; 3).Prasarana yang sudah tidak memadai baik dari segi kondisi maupun jumlahnya.

Rekomendasi yang dapat diberikan yaitu: Perlunya konstitensi penegakkan Peraturan Daerah Kota Kendari Nomor 3 Tahun 2016 serta Peraturan Walikota Kendari 
Nomor 18 Tahun 2018 yang ditunjang oleh sarana dan prasarana serta personil yang memadai baik dari segi kuantitas mapun kualitas dan pengawasan yang efektif terhadap pengelolaan air limbah domestik yang di buang ke teluk Kendari membutuhkan anggaran, personil serta prasarana yang sesuai dengan proporsi dimana luasnya teluk dan banyaknya warga sebagai obyek pengawasan.

\section{UCAPAN TERIMA KASIH}

Penulis mengucapkan terima kasih kepada Lembaga Penelitian dan Pengabdian Kepada Masyarakat (LPPM), Universitas Muhammadiyah Kendari yang telah memberikan dukungan financial dalam penelitian ini.

\section{DAFTAR PUSTAKA}

Amirudin\& Zainal Asikin, 2014.Pengantar Metode Penelitian Hukum. Jakarta: PT Raja Grafindo Persada.

Deni Bram, 2014.Hukum Lingkungan Hidup. Bekasi: Gramata Publishing.

http://www.mongabay.co.id/2017/12/12/kala-teluk-kendari-tercemar-merkuri-danlimbah-b3/. diakses Minggu, 30 Desember 2018.

https://revitalisasikawasan-upn.blogspot.com/2016/06/revitalisasi-kawasan-telukkendari.html, diakses Sabtu 21 September 2019

King Faisal Sulaiman, 2017. Teori Peraturan Perundang-Undangan Dan Aspek Pengujiannya. Yogyakarta: Thafa Media.

Mukti Fajar dan Yulianto Achmad, 2010. Dualisme Penelitian Hukum Normatif\&Empiris. Yogyakarta: Pustaka Pelajar.

Nomensen Sinamo, 2015. Hukum Lingkungan Indonesia. Tangerang: PT Pustaka Mandiri.

Peraturan Pemerintah Nomor 82 Tahun 2001 tentang Pengelolaan Kualitas Air dan Pengendalian Pencemaran.

Permen LHK No. P.68/Menlhk/Setjen/Kum.1/8/2016 tentang Baku Mutu Air Limbah Domestik.

Ronny Hanitijo Soemitro, 2001. Metodologi Penelitian Hukum dan Jurimetri. Jakarat: Ghalia Indonesia.

Samsul Wahidin, 2017. Politik Penegakan Hukum Di Indonesia . Yogyakarta: Pustaka Pelajar.

Takdir Rahmadi, 2015 . Hukum Lingkungan di Indonesia. Jakarta: Rajawali Pers Undang-Undang Nomor 12 Tahun 2011 tentang Pembentukan Perundang-undangan. Undang-Undang Nomor 32 Tahun 2009 Tentang Perlindungan dan Pengelolaan Lingkungan Hidup. 